\title{
Potentiation of ionising radiation by targeting tumour necrosis factor alpha using a bispecific antibody in human pancreatic cancer
}

\author{
D Azria', , C Larbouret', V Garambois', A Kramar ${ }^{3}$, P Martineau ${ }^{4}$, B Robert', N Aillères ${ }^{5}$, M Ychou ${ }^{1,6}$, \\ JB Dubois ${ }^{1,2}$ and A Pèlegrin ${ }^{*, 1}$
}

'Tumour Immunotargeting and Antibody Engineering, INSERM, EMI 0227, 34298 Montpellier, France; 'Department of Radiation Oncology, Val d'Aurelle Cancer Institute, 34298 Montpellier, France; ${ }^{3}$ Biostatistics Unit, Val d'Aurelle Cancer Institute, 34298 Montpellier, France; ${ }^{4}$ Center for Pharmacology and Health Biotechnology, CNRS, 34000 Montpellier, France; ${ }^{5}$ Department of Radiophysics, Val d'Aurelle Cancer Institute, 34298 Montpellier, France;

${ }^{6}$ Department of Medical Oncology, Val d'Aurelle Cancer Institute, 34298 Montpellier, France

\begin{abstract}
The aim of this study was to treat carcinoembryonic antigen (CEA)-expressing pancreatic carcinoma cells with tumour necrosis factor alpha (TNF $\alpha$ ) and simultaneous radiation therapy (RT), using a bispecific antibody (BAb) anti-TNF $\alpha$ /anti-CEA. TNF $\alpha$ used alone produced a dose-dependent inhibition of the clonogenic capacity of the cultured cells. Flow cytometry analysis of cell cycle progression confirmed the accumulation of cells in $G_{1}$ phase after exposure to TNF $\alpha$. When TNF $\alpha$ was added $12 \mathrm{~h}$ before RT, the surviving fraction at $2 \mathrm{~Gy}$ was $60 \%$ lower than that obtained with irradiation alone $(0.29$ vs 0.73 , respectively, $P<0.0000$ I). In combination treatment, cell cycle analysis demonstrated that TNF $\alpha$ reduced the number of cells in radiation-induced $\mathrm{G}_{2}$ arrest, blocked irreversibly the cells in $G_{1}$ phase, and showed an additive decrease of the number of cells in $S$ phase. In mice, RT as a single agent slowed tumour progression as compared with the control group $(P<0.0000 \mathrm{I})$. BAb $+\mathrm{TNF} \alpha+\mathrm{RT}$ combination enhanced the delay for the tumour to reach $1500 \mathrm{~mm}^{3}$ as compared with $\mathrm{RT}$ alone or with $\mathrm{RT}+\mathrm{TNF} \alpha(P=0.00 \mathrm{I} \mathrm{I})$. Median delays were 90 , 93, and I 42 days for RT alone, RT + TNF $\alpha$, and RT + BAb + TNF $\alpha$ groups, respectively. These results suggest that TNF $\alpha$ in combination with BAb and RT may be beneficial for the treatment of pancreatic cancer in locally advanced or adjuvant settings.

British Journal of Cancer (2003) 89, 1987-1994. doi:I0.1038/sj.bjc.6601362 www.bjcancer.com
\end{abstract}

(c) 2003 Cancer Research UK

Keywords: bispecific antibody; tumour necrosis factor alpha; pancreas cancer; radiation enhancement

Adenocarcinoma of the pancreas remains one of the most difficult malignancies to treat. The incidence has steadily increased over the past four decades (Gudjonsson, 1987), and its prognosis is still dismal, despite tremendous efforts in early diagnosis and therapy. The 5 -year survival rate is less than $5 \%$ with a complete surgical resection (Gudjonsson, 1987), ranking this cancer fourth among the leading causes of cancer death (Parker et al, 1996). Unfortunately, at the time of diagnosis, the majority of patients $(80-90 \%)$ have locally or metastatic inoperable tumours. Radiation therapy (RT) alone or in combination with chemotherapy showed modest efficacy in local control and palliation (Andre et al, 2000; Kornek et al, 2000; Azria et al, 2002). Despite these intensive efforts to improve the efficacy of conventional therapy, no satisfactory progress in dealing with this cancer has been made. Accordingly, new treatment modalities are required for this tumour.

Current interest has focused on biological response modifiers as antineoplastic agents. Among them, tumour necrosis factor alpha $(\mathrm{TNF} \alpha)$ was originally identified as a tumoricidal protein effecting haemorrhagic necrosis of transplanted solid tumours in mice

* Correspondence: Dr A Pelegrin, Centre de recherche en cancérologie, Centre Régional de Lutte contre le Cancer Val d'Aurelle-Paul Lamarque, Parc Euromédecine, 34298 Montpellier Cedex 5, France;

E-mail: apelegrin@valdorel.fnclcc.fr

Received 12 June 2003; revised 4 September 2003; accepted 4 September 2003
(Carswell et al, 1975). It is a multipotent cytokine produced mainly by activated macrophages with the ability to mediate cytotoxicity both in vitro (Sugarman et al, 1985) and in vivo (Carswell et al, 1975; Helson et al, 1979). TNF $\alpha$ usually does not kill untransformed cells (Sugarman et al, 1985) but shows an antiproliferative effect on certain tumour cells in vitro by still undefined mechanisms. Recently, Ruegg et al (1998) reported evidence for the involvement of endothelial cell integrin $\alpha \mathrm{v} \beta 3$ in the disruption of the tumour vasculature induced by the combination of TNF $\alpha$ and IFN $\gamma$.

Several in vitro clonogenic assays suggest that an additive or a supra-additive interaction may occur between TNF $\alpha$ and ionising radiation (Hallahan et al, 1990; Gridley et al, 1994a; Azria et al, 2003a) as well as an enhancement of the antitumour effect of radiation in some murine and human tumours in vivo (Sersa et al, 1988; Nishiguchi et al, 1990; Gridley et al, 1997; Azria et al, 2003a). The oxidative damage produced by TNF $\alpha$ (Zimmerman et al, 1989) may enhance cellular damage produced by ionising radiation. In addition, $\mathrm{TNF} \alpha$ and radiation can induce apoptosis in target cells (Yamada and Ohyama, 1988; Langley et al, 1993) even if cells are normally highly resistant to the induction of radiation-induced apoptosis (Kimura et al, 1999).

In different clinical trials using systemic injection of $\mathrm{TNF} \alpha$, the results have been disappointing mainly because patients were found to have significantly lower maximum tolerated doses (Abbruzzese et al, 1989; Moritz et al, 1989) as compared with mice (Asher et al, 1987; Havell et al, 1988). These limited results were probably due to the short circulatory half-life of TNF $\alpha$ and its 
severe systemic side effects. Studies involving regional (Lienard et al, 1992; Mavligit et al, 1992; Lejeune et al, 1998) or intratumoral (van der Schelling et al, 1992) injection of TNF $\alpha$ have demonstrated its potential for cancer therapy, but only when a high enough therapeutic concentration of $\mathrm{TNF} \alpha$ was obtained in the tumour with a nontoxic systemic concentration. To overcome this limitation, we used previously a bispecific antibody (BAb) directed against carcinoembryonic antigen (CEA) and $\mathrm{TNF} \alpha$ to target this cytokine in human CEA-expressing colorectal carcinoma treated simultaneously with RT (Azria et al, 2003a).

In the present study, we report the results of clonogenic tests of pancreatic (BxPC-3) cell survival, which confirm a superiority of the radiation-TNF $\alpha$ combination as compared with radiation alone. We show here a nonreversible cell cycle arrest of these cells treated by $\mathrm{TNF} \alpha$ alone or in combination with ionising radiation. Using nude mice-bearing BxPC-3 xenografts, we showed a significant enhanced tumour growth delay when the $\mathrm{BAb}+$ $\mathrm{TNF} \alpha+\mathrm{RT}$ combination was used as compared with RT alone and with RT $+\mathrm{TNF} \alpha$.

\section{MATERIALS AND METHODS}

\section{Cell line and cell culture}

The CEA-expressing human pancreatic carcinoma BxPC-3 cell line (Tan et al, 1986) was obtained from the American Type Culture Collection (Rockville, MD, USA). The cells were cultured in RPMI1640 medium (Gibco Laboratories, France) supplemented with $10 \%$ heat-inactivated fetal calf serum (Gibco Laboratories, France), $300 \mu \mathrm{g} \mathrm{ml}^{-1}$ glutamine, $0.25 \mu \mathrm{g} \mathrm{ml}^{-1}$ fungizone, $100 \mu \mathrm{g} \mathrm{ml}^{-1}$ streptomycin, and $100 \mathrm{U} \mathrm{ml}^{-1}$ penicillin $\mathrm{G}$. These cells were adherent and grew as monolayers at $37^{\circ} \mathrm{C}$ in a humidified $5 \% \mathrm{CO}_{2}$ incubator. The BxPC-3 cells were harvested with $0.5 \mathrm{gl}^{-1}$ trypsin (Gibco Laboratories, France) and $0.2 \mathrm{gl}^{-1}$ EDTA (Gibco Laboratories, France) for $3 \mathrm{~min}$. Cultures were checked for the absence of mycoplasma every month.

\section{$\mathrm{TNF} \alpha$ and $\mathrm{BAb}$}

Recombinant human TNF $\alpha$, kindly provided by Dr GR Adolf (Boehringer Ingelheim, Wien, Austria), was prepared by expression of a synthetic gene in Escherichia coli. The specific activity of $\mathrm{TNF} \alpha$, determined in the presence of actinomycin $\mathrm{D}$, was $5 \times 10^{7} \mathrm{U} \mathrm{mg}^{-1}$ protein as determined by cytolysis of murine L929 cells. TNF $\alpha$ (at a concentration of $2.5 \mathrm{mg} \mathrm{ml}^{-1}$ ) was stored at $-80^{\circ} \mathrm{C}$ until use.

$\mathrm{BAb}$ was constructed as previously described (Robert et al, 1996) from the anti-CEA MAb 35A7 (Haskell et al, 1983) and the MAb tnf18 kindly provided by Dr M Brockhaus (Hoffmann-La Roche AG, Basel, Switzerland).

\section{Radiation protocols}

Cells were plated in $10 \mathrm{ml}$ RPMI (to ensure homogeneous energy deposition within each dish) using 60-mm Petri dishes and irradiated with a cobalt-60 $\left({ }^{60} \mathrm{Co}\right)$ source $(\gamma$-irradiation, ELITE 100 , Theratronics) in the Radiation Department. The radiation was delivered as a single dose ranging from 2 to $10 \mathrm{~Gy}$ in an $11 \mathrm{~cm} \times 11 \mathrm{~cm}$ field size at a dose rate of $0.5 \mathrm{~Gy} \mathrm{~min}^{-1}$. A $3-\mathrm{cm}$ polystyrene block was used under the Petri dishes during each irradiation to allow homogeneous back-scattering $\gamma$-rays. Sourcehalf depth distance (SHD) was initially calculated to obtain a constant dose rate of $0.5 \mathrm{~Gy} \mathrm{~min}^{-1}$ and monthly adapted from the ${ }^{60} \mathrm{Co}$ source radioactivity decrease. Control cells were removed from the incubator and placed for the same period of time under the ${ }^{60} \mathrm{Co}$ source but without radiation treatment. In the combined treatment modality studies, TNF $\alpha$ was added $12 \mathrm{~h}$ prior to RT (see Results, 'TNF $\alpha$ enhances radiosensitivity').

For in vivo tumour treatment, the radiation was delivered to the flank of five mice simultaneously in a $12.5 \mathrm{~cm} \times 12.5 \mathrm{~cm}$ field size at $6 \mathrm{~Gy}$ fraction ${ }^{-1}$ at a dose rate of $0.5 \mathrm{~Gy} \mathrm{~min}^{-1}$ (SHD of $158 \mathrm{~cm}$ ), twice a week, for a total dose of $30 \mathrm{~Gy}$. A 6-cm thickness lead block with eight circular apertures, $3 \mathrm{~cm}$ in diameter, was used so that only the tumours and the underlying normal tissues were exposed to the radiation. Radiation was measured using dosimetry films (RA711P, Agfa, Belgium).

Immediately prior to irradiation, the mice were anaesthetised by intraperitoneal injection of $233 \mu \mathrm{gg}^{-1}$ of tribromoethanol dissolved in an ethanol:saline combination $\left(1: 10, \mathrm{vv}^{-1}\right)$. The anaesthetic was given to all mice, regardless of treatment group, to equalise the effects due to stress.

\section{Clonogenic assay}

The colony-forming assay and growth curve analyses were used to assess the sensitivity of the BxPC-3 cells to TNF $\alpha$. Cultures were trypsinised, washed, and cells were plated in quintuplicate at a density of 100 per $60-\mathrm{mm}$ Petri dishes. TNF $\alpha$ was added at concentrations ranging from 0.3 to $5000 \mathrm{U} \mathrm{ml}^{-1} 12 \mathrm{~h}$ after the cells were plated to allow for cell attachment. Cells were incubated at $37^{\circ} \mathrm{C}$ in a humidified chamber containing $5 \% \mathrm{CO}_{2}$ for 12 days. The colonies were then fixed with a $1: 3\left(\mathrm{vv}^{-1}\right)$ acetic acid:methanol solution and stained with $10 \%$ Giemsa (Sigma Chemical Co., St Louis, MO, USA); colonies of more than 50 cells were scored. Plating efficiency was calculated with and without TNF $\alpha$. The dose-response curves were fitted to a four-parameter logistic model, where the response, $R$, varies with the dose, $D$, according to the equation: $R=a /\left(1+(D / b)^{c}\right)+R$, where $a$ is the difference between the maximum and minimum response, $b$ is the concentration of drug needed to obtain $50 \%$ of the maximal effect, $c$ is a slope factor, and $R$ is the maximal effect. The cytotoxic effect of irradiation on asynchronous, exponentially growing BxC-3 cells was also determined by the colony-forming assay. Before irradiation, cell density was determined using appropriate dilutions $(100,300,600$, and 1600 cells for $0,2,4$, and $6 \mathrm{~Gy}$, respectively), and five replicates of each dilution were plated in $60-\mathrm{mm}$ Petri dishes. Cells were irradiated as described above, $24 \mathrm{~h}$ after plating to allow for cell attachment prior to the administration of radiation. The $\mathrm{TNF} \alpha$-containing medium was given at a concentration of $625 \mathrm{U} \mathrm{ml}^{-1} 12 \mathrm{~h}$ before irradiation. A dose of $625 \mathrm{U} \mathrm{ml}^{-1}$ of $\mathrm{TNF} \alpha$ was chosen because colony-forming assays showed that this dose was sufficient to induce only partial $(48 \%$ survival) cell growth when the cytokine was used alone. Cultures were irradiated when the drug was in the medium and were immediately returned to the incubator after irradiation. Colonies were counted after 14 days. Experimentally derived data points are the mean of three experiments. The multitarget model survival curves were fit to the data using a least-squares regression to the linear-quadratic model, $S=S_{0} \exp \left(-\alpha D_{1}-\beta D_{1}^{2}\right)$, where $D_{1}$ is the radiation dose, $S$ the surviving fraction, and $S_{0}$ a normalising parameter.

\section{Flow cytometry}

Cells were plated in $60-\mathrm{mm}$ Petri dishes at a density of $5 \times 10^{6}$ cells dish $^{-1}$. Treatment consisted of TNF $\alpha\left(625 \mathrm{U} \mathrm{ml}^{-1}\right)$ alone at $24 \mathrm{~h}$ (H24), RT (4 Gy) at H36, or TNF $\alpha\left(625 \mathrm{U} \mathrm{ml}^{-1}\right.$ at H24) + RT (4 Gy at H36). Cells were collected at 48 and $96 \mathrm{~h}$ after cell culture and processed for cell cycle analysis. Cells were harvested by trypsinisation, washed with $\mathrm{PBS}$, and then $1 \times 10^{6}$ cells dish $^{-1}$ of treatments were fixed in $70 \%$ ethanol for $2 \mathrm{~min}$. After removal of ethanol by centrifugation, cells were then stained with a solution containing $40 \mu \mathrm{g} \mathrm{ml}^{-1}$ propidium iodide (Sigma, St Louis, USA) and $0.1 \mathrm{mg} \mathrm{ml}^{-1}$ RNase A (Roche, Indianapolis, USA). Stained 
nuclei were analysed for DNA-PI fluorescence using a Becton Dickinson FACScan flow cytometer. Resulting DNA distributions were analysed by the CellQUEST software (Becton Dickinson, Mountain View, CA, USA) for the proportion of cells in sub-G0, G1, S, and G2 - M phases of the cell cycle.

In a second series of experiments, cells were treated with TNF $\alpha$ $\left(625 \mathrm{U} \mathrm{ml}^{-1}\right.$ ) alone at $\mathrm{H} 24$ and then cultured for 3 days. Medium was then harvested and replaced by RPMI. Cells were stained at different time points up to 21 days and analysed for DNA content on a FACScan as described above.

\section{In vivo model}

All the in vivo experiments were performed in compliance with the French guidelines for experimental animal studies (Agreement No. A34220) and fulfil the UKCCCR Guidelines for the welfare of animals in experimental neoplasia.

Mice Athymic 7-9-week-old female Swiss nude mice (nu/nu, Iffa Credo, l'Arbresle, France) were housed in self-contained filtertop cages (five mice cage ${ }^{-1}$ ) in a facility controlled for temperature, humidity, and a $12: 12 \mathrm{~h}$ light: dark cycle under sterile conditions. The animals were given autoclaved food and water ad libitum.

Experimental protocols The human pancreatic carcinoma $\mathrm{BxPC}-3$ cells were harvested with $0.25 \%$ trypsin solution, washed, and adjusted to $2 \times 10^{6} 150 \mu \mathrm{l}^{-1}$ RPMI-1640 medium without fetal calf serum. Each mouse was injected s.c. in the right flank with $150 \mu \mathrm{l}$ of the cell suspension. After 35 days, the mice were grouped according to tumour size by measuring tumour diameters with a Vernier caliper to avoid nonhomogeneous groups before beginning treatments. Tumour dimensions were measured twice weekly and volumes $\left(\mathrm{mm}^{3}\right)$ were estimated by the formula $d_{1} \times d_{2} \times d_{3} / 2$, where $d_{1}$ is the length, $d_{2}$ is the width, and $d_{3}$ is the height of the tumour.

On day 35 , the mice were assigned to seven different treatment groups (five mice per group) as follows:

Group 1: $0.9 \% \mathrm{NaCl}$ i.v. injection alone $\left(200 \mu\right.$ injection $\left.^{-1}\right)$ for this control group on days $34,37,41,44$, and 48 .

Group 2: TNF $\alpha$ at $1 \mu$ i.v. $^{-1}$ injection alone (in $200 \mu \mathrm{l} 0.9 \% \mathrm{NaCl}$ injection $^{-1}$ ) on days $34,37,41,44$, and 48 .

Group 3: BAb at $25 \mu \mathrm{g}$ i.v. ${ }^{-1}$ injection alone (in $200 \mu \mathrm{l} 0.9 \% \mathrm{NaCl}$ injection $^{-1}$ ) on days $33,36,40,43$, and 47 .

Group 4: $\mathrm{BAb}+\mathrm{TNF} \alpha$ (ratio $25 \mu \mathrm{g}: 1 \mu \mathrm{g}$; molar ratio $12.5: 1$ ) i.v. injection (in $200 \mu \mathrm{l} 0.9 \% \mathrm{NaCl}$ injection $^{-1}$ ) on days 33, 36, 40, 43, and 47 . BAb-TNF $\alpha$ mixture was prepared $24 \mathrm{~h}$ before injection.

Group 5: Local radiation as described above delivered on days $34,37,41,44$, and $48+0.9 \% \mathrm{NaCl}$ i.v. injection $\left(200 \mu\right.$ injection $\left.^{-1}\right)$ $3 \mathrm{~h}$ before irradiation.

Group 6: Local radiation as described above delivered on days $34,37,41,44$, and $48+\mathrm{TNF} \alpha$ i.v. injection administered using the same time-dose schedules as for group 2 with TNF $\alpha$ injections $3 \mathrm{~h}$ before irradiation

Group 7: Local radiation $+\mathrm{BAb}+\mathrm{TNF} \alpha$ administered using the same time-dose schedules as for group 4 concerning BAb $+\mathrm{TNF} \alpha$ and group 5 in regard to radiation.

All i.v. injections were performed in the heat dilated tail vein; the day of tumour implantation was day 0 . On the basis of the biodistribution studies of TNF $\alpha$ and $\mathrm{BAb}-\mathrm{TNF} \alpha$ complexes (Robert et al, 1996), we decided to inject TNF $\alpha 3 \mathrm{~h}$ prior to RT (group 6) and BAb-TNF $\alpha$ complexes $24 \mathrm{~h}$ prior to RT (group 7).

The mice were weighed twice a week and routinely observed for signs of toxicity throughout the study particularly digestive toxicity because of the local flank irradiation.

\section{Statistical analyses}

The nonparametric Wilcoxon's signed-rank test was used to compare the surviving fraction between the two groups (RT alone and $\mathrm{RT}+\mathrm{TNF} \alpha$ ). For in vivo experiments, the results were expressed in terms of the time taken for the tumour to reach a volume of $1500 \mathrm{~mm}^{3}$. The Kaplan-Meier method was used to estimate the median time taken to reach a tumour volume of at least $1500 \mathrm{~mm}^{3}$. Differences among treatment groups were tested by the log-rank test. All statistical tests were two-sided with an $\alpha$ level of 0.05. Data were analysed with software STATA 7.0 (Stata Corporation, College Station, TX, USA).

\section{RESULTS}

\section{TNF $\alpha$ inhibits BxPC-3 proliferation}

The cytotoxic effects of increasing concentrations of TNF $\alpha(0.3-$ $5000 \mathrm{U} \mathrm{ml}^{-1}$ ) on asynchronous, exponentially growing BxPC-3 cells were determined in colony-forming assays. Cell survival followed a dose-response curve fitted to a four-parameter logistic model as described in Materials and Methods.

Cells were killed by concentrations of TNF $\alpha$ as low as $10 \mathrm{U} \mathrm{ml}^{-1}$ (Figure 1A). The $\mathrm{LC}_{50}$, defined as concentration of drug that reduced the cell survival rate to $50 \%$ of that of the controls, was $625 \mathrm{U} \mathrm{ml}^{-1}$. Next, BxPC-3 cells were treated with TNF $\alpha$ $\left(625 \mathrm{U} \mathrm{ml}^{-1}\right)+\mathrm{BAb}$ (molar ratio of $100: 1,1: 1$, or $\left.1: 100\right)$ and plating efficiencies were compared with that obtained with TNF $\alpha$ alone. No difference in the surviving fraction was observed when $\mathrm{BAb}$ was added to $\mathrm{TNF} \alpha$ at the same or lower molar ratio. In contrast, when $\mathrm{BAb}$ was added in a 100 -fold excess, the surviving fraction of cells exposed to $2 \mathrm{~Gy}$ was $30 \%$ greater than that observed with TNF $\alpha$ alone, probably due to competition between the anti-TNF $\alpha$ arm of the BAb in solution and the TNF $\alpha$ receptor on the cell surface.

\section{TNF $\alpha$ enhances radiosensitivity}

Cell survival following irradiation (Figure 1B) in aerated medium fit a linear quadratic model as described in Materials and Methods. The surviving fraction at $2 \mathrm{~Gy}(\mathrm{SF} 2)$ was 0.73 and a $\mathrm{D}_{0}$ (dose of radiation giving $37 \%$ survival rate) of $4 \mathrm{~Gy}$ when irradiation was used alone. As shown in Figure 2, TNF $\alpha$ added $12 \mathrm{~h}$ before RT (H12) led to a significant decrease of the surviving fractions as compared with those obtained when $\mathrm{TNF} \alpha$ was added at $\mathrm{H}-1$ or $\mathrm{H}+12(P=0.02)$ or when RT was delivered alone. For further experiments using RT with $\mathrm{TNF} \alpha$, we used $\mathrm{TNF} \alpha$ at a concentration of $625 \mathrm{U} \mathrm{ml}^{-1}$ added $12 \mathrm{~h}$ before RT. In this combination treatment, SF2 and $\mathrm{D}_{0}$ were 0.29 and $1.2 \mathrm{~Gy}$, respectively. SF2 was $60 \%$ lower in combination treatment with a significant test result $(P<0.00001)$. When the data were analysed according to the linear quadratic model, the $\alpha$ and $\beta$ components were $0.188 \pm 0.08$ and $0.017 \pm 0.011 \mathrm{~Gy}^{-2}$, respectively, without $\mathrm{TNF} \alpha$ and $0.39 \pm 0.06 \mathrm{~Gy}^{-1}$ and nearly $0 \mathrm{~Gy}^{-2}$ in combination treatments. These data indicate that treatment with $\mathrm{TNF} \alpha$ results in a steeper decline in cell survival due both to a higher initial slope of the dose-response curve and a major decrease of the quadratic parameter. These results show possible additivity between the two treatments, as confirmed by isobologram analysis (Azria et al, 2003b).

\section{TNF $\alpha$ induces $G_{1}$ cell cycle arrest}

The effect of TNF $\alpha$ treatment on cell cycle phase distribution in BxPC-3 cell line was evaluated using flow cytometry (Figure 3). Treatment with $625 \mathrm{U} \mathrm{ml}^{-1} \mathrm{TNF} \alpha$ for $24 \mathrm{~h}$ induced accumulation of cells in $G_{1}$ phase $(72.8 \%)$ with a significant decrease in the percentage of cells in S phase (20.3\%) relative to controls (49.6 and 

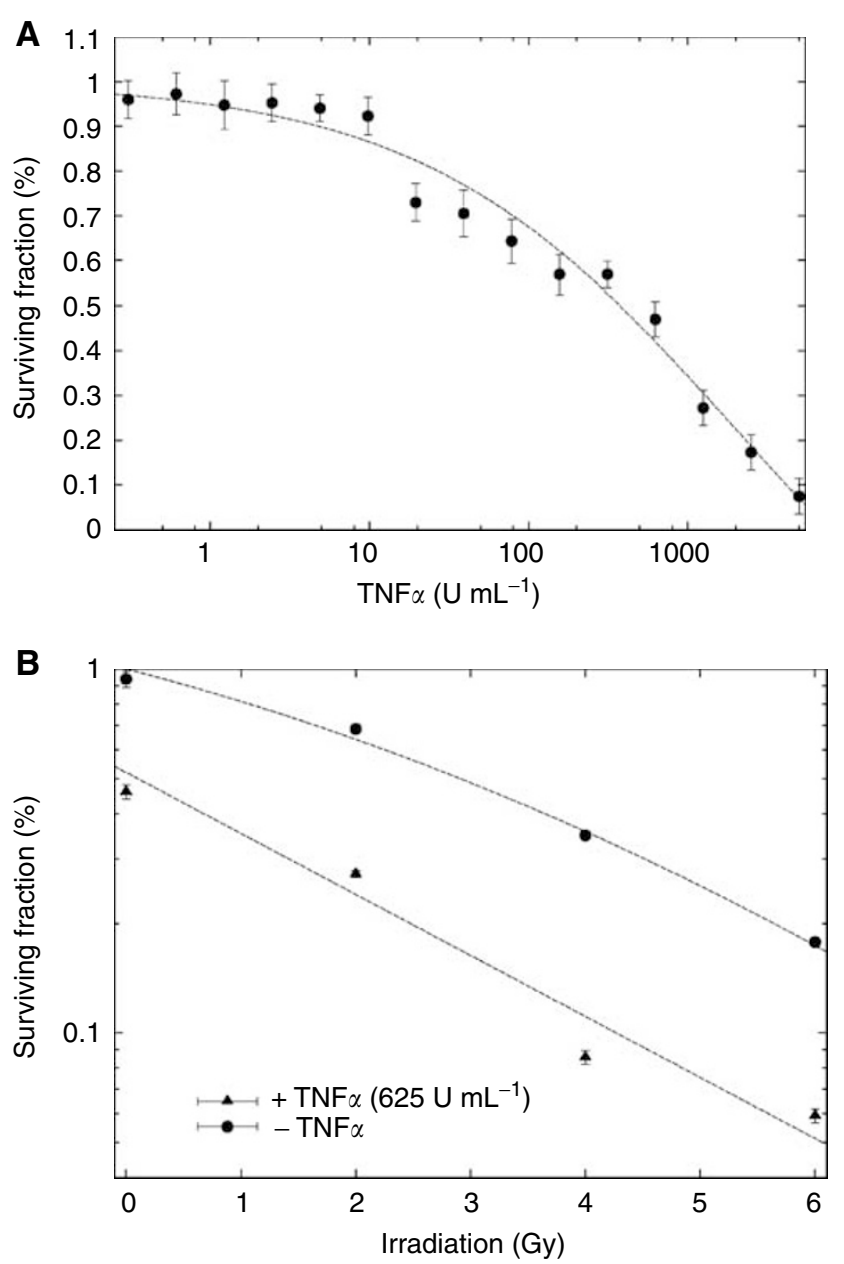

Figure I Dose-response curves of the effects of TNF $\alpha$ and irradiation treatment of BxPC-3 cells. (A) Response of BxPC-3 cells to TNF $\alpha$. Cells were grown in the presence of increasing concentrations of TNF $\alpha(0.3-$ $5000 \mathrm{U} \mathrm{ml}^{-1}$ ). Plating efficiencies were compared with controls grown without TNF $\alpha$ (I00\% survival). (B) Response of BxPC-3 cells, treated or not with TNF $\alpha$, to radiation. BxPC-3 cells treated with TNF $\alpha\left(625 \mathrm{Uml}^{-1}\right)$ added $12 \mathrm{~h}$ prior to irradiation showed a surviving fraction at $2 \mathrm{~Gy}$, which was statistically lower $(P<0.0000 \mathrm{I})$ than when combination treatment was used. When the data were analysed according to the linear quadratic model, the $\alpha$ and $\beta$ components were, respectively, $0.188 \pm 0.08 \mathrm{~Gy}^{-1}$ and $0.017 \pm 0.011 \mathrm{~Gy}^{-2}$ without TNF $\alpha$ and $0.39 \pm 0.06 \mathrm{~Gy}^{-1}$ and about $0 \mathrm{~Gy}^{-2}$ in combination treatments.

$37.8 \%$, respectively) (Figure $3 \mathrm{~A}$ and $\mathrm{B}$ ). No cells with subdiploid DNA content was observed, consistent with other results on human colorectal cell line LS174T (Azria et al, 2003b) demonstrating that TNF $\alpha$ does not induce apoptosis in these cell lines. After 3 days of treatment, cells were washed and further cultured for 21 days in the absence of the cytokine. We observed a nonreversible G1 cell cycle arrest (nearly $70 \%$ at day 21 ) without any renewal of activity of the S phase as compared to day 3 after TNF $\alpha$ treatment (Table 1)

At 1 day after RT alone, we observed a cell cycle arrest in the $\mathrm{G}_{2}$ phase $(40 \%)$ with a decrease in the percentage of cells in the G0/G1 and $\mathrm{S}$ phases as compared with the control (39vs 50\% and 21 vs $38 \%$, respectively). When $\mathrm{TNF} \alpha$ was added $12 \mathrm{~h}$ before $\mathrm{RT}$, the radiation-induced $\mathrm{G}_{2} / \mathrm{M}$ arrest decreased as compared with RT alone (31 vs $40 \%$, respectively) with a TNF $\alpha$-induced $\mathrm{G}_{0} / \mathrm{G}_{1}$ blockade and a very low $\mathrm{S}$ phase (Figure $3 \mathrm{C}$ and $\mathrm{D}$ ).

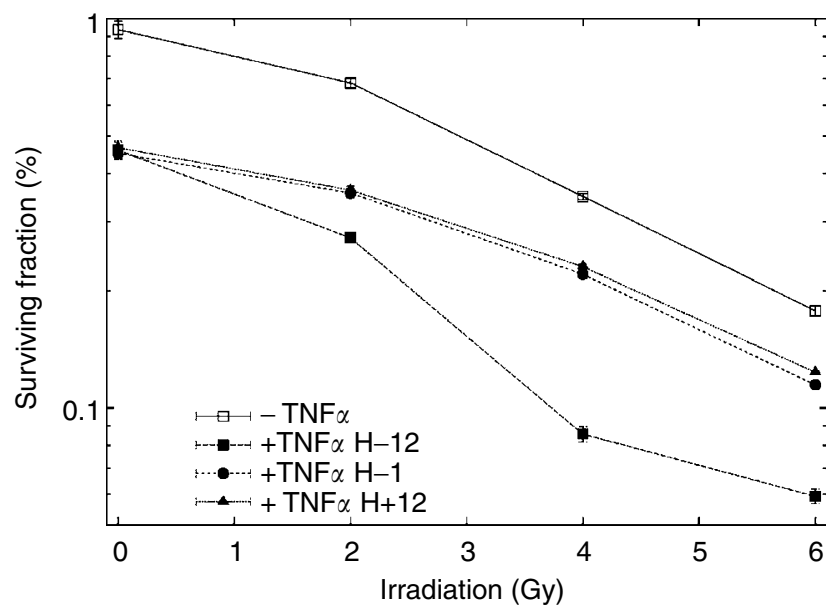

Figure 2 Effect of TNF $\alpha$ on the radiosensitivity of $\mathrm{BxPC}-3$ cells. The influence of TNF $\alpha$ added $12 \mathrm{~h}$ before, I $\mathrm{h}$ before, or $12 \mathrm{~h}$ after RT. Results are expressed in terms of the surviving fraction as described in Materials and Methods. Cells were exposed to TNF $\alpha\left(625 \mathrm{U} \mathrm{ml}^{-1}\right)$ and irradiated at the different time points. Control cells were exposed to radiation without TNF $\alpha$ treatment.

\section{$\mathrm{BAb}+\mathrm{TNF} \alpha$ augments in vivo tumour response to radiation}

BxPC-3 tumours growing s.c. in the right flank of nude mice were used to test the antitumour activity of TNF $\alpha$ alone or in combination with RT. TNF $\alpha$ was injected i.v. alone or coinjected with the anti-CEA/anti-TNF $\alpha$ BAb (BAb-TNF $\alpha$ mixture was prepared $24 \mathrm{~h}$ before injection at a molar ratio of $12.5: 1)$. Median pretreatment tumour volumes (day 35) were $128(6-135) \mathrm{mm}^{3}$ with no statistical difference between the groups. Tumour growth was then measured regularly until tumours were larger than $1500 \mathrm{~mm}^{3}$. Radiation alone (group 5), but not TNF $\alpha$ alone (group 2 ), significantly inhibited tumour progression as compared with the control group $(P<0.00001)$. No difference in growth delay was observed between the control group and groups without RT (groups 2-4). During the same period of observation, treatment with TNF $\alpha$ slowed tumour growth in irradiated groups, particularly when $\mathrm{TNF} \alpha$ was coinjected with BAb. At day 93 , when mice in all other groups were killed (tumour $>1500 \mathrm{~mm}^{3}$ ), the median value of the tumour volume was $260 \mathrm{~mm}^{3}$ for the RT $+\mathrm{BAb}+\mathrm{TNF} \alpha$ group.

The results expressed in terms of the time to reach $1500 \mathrm{~mm}^{3}$ are shown in Figure 4. In the control group and the groups treated with $\mathrm{TNF} \alpha, \mathrm{BAb}$, or $\mathrm{BAb}+\mathrm{TNF} \alpha$, the median delay for the mice to reach a tumour volume greater than $1500 \mathrm{~mm}^{3}$ was $62,62,65$, and 62 days, respectively, with no statistical difference between the groups. In the RT-treated groups, the median delays were 90, 93, and 142 days for the RT alone, the $\mathrm{RT}+\mathrm{TNF} \alpha$, and the $\mathrm{RT}+\mathrm{BAb}+\mathrm{TNF} \alpha$ groups, respectively. No statistical difference was observed between the RT and RT $+\mathrm{TNF} \alpha$ groups. However, in the presence of the BAb, the curve for group 7 was shown to be statistically different from the growth curves for tumours treated with $\mathrm{RT}$ alone or $\mathrm{RT}+\mathrm{TNF} \alpha(P=0.0011)$.

At the end of all treatments, no significant differences were found in mouse body weight between the seven groups. The mean \pm s.e.m. were $23.1 \pm 0.47,22.4 \pm 0.87,23.6 \pm 0.61,24 \pm 0.65$, $24 \pm 0.37,24.4 \pm 0.41,23.7 \pm 0.54$ for groups $1,2,3,4,5,6,7$, respectively. No diarrhoea was observed in any group, suggesting the absence of digestive toxicity. No significant fluid retention, respiratory distress, or other signs of toxicity were observed in any of the animals during the course of the study. 

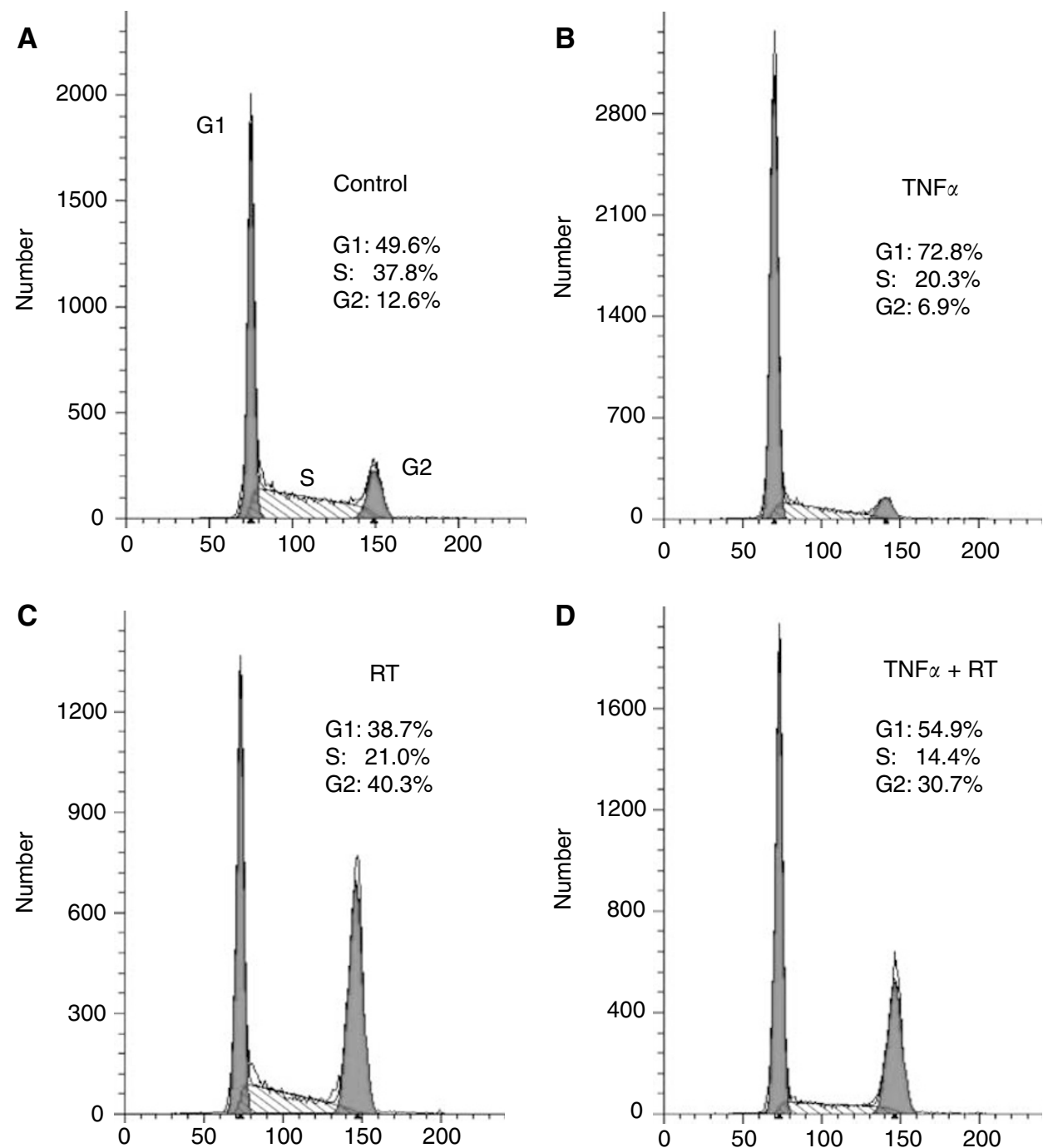

Figure 3 Effect of TNF $\alpha$ orland RT on BxPC-3 cell cycle progression. BxPC-3 were harvested after $36 \mathrm{~h}$ exposure to TNF $\alpha$ and compared with control cells $(\mathbf{B})$ and $(\mathbf{A})$, respectively). In the case of RT treatment, cells were harvested I $2 \mathrm{~h}$ after RT with or without TNF $\alpha$ (added I2 h before RT) (C and $\mathbf{D})$. Cells were fixed and stained with PI for flow cytometry analysis as described in 'Materials and Methods.' Percentages of $G_{0} / G_{1}, S$, and $G_{2} / M_{\text {were }}$ determined by CellQUEST analysis software on the basis of DNA content of the histogram. Data represent mean values of duplicate samples. Similar results were obtained in replicate experiments.

Table I Cell cycle distributions ${ }^{\mathrm{a}}$ at different times after treatment by TNF $\alpha$ in comparison with control (day 0)

\begin{tabular}{lcccccc}
\hline Cycle phases & Day 0 & Day I & Day 3 & Day 7 & Day I4 & Day 2 I \\
\hline $\mathrm{G}_{0} / \mathrm{G}_{1}$ & $50^{\mathrm{b}}$ & 73 & 72 & 80 & 78 & 72 \\
$\mathrm{~S}$ & 38 & 20 & 16 & 12 & 12 & 14 \\
$\mathrm{G}_{2} / \mathrm{M}$ & 12 & 7 & 12 & 8 & 10 & 14 \\
\hline
\end{tabular}

${ }^{a}$ After 3 days of treatment, cells were washed and further cultured for 21 days in the absence of the cytokine. Cells were fixed and stained with PI for flow cytometry analysis at different time points up to 21 days. DNA histograms were modelled with CellQUEST analysis software and phase percentages for G0/GI, S, and G2/M were determined. ${ }^{b}$ Results are expressed as mean values (\%) of triplicate samples. Similar results were obtained in six independent experiments.

\section{DISCUSSION}

Pancreatic carcinoma is the fourth leading cause of cancer deaths. Patient survival of this devastating disease is bleak with less than $5 \%$ of patients surviving 5 years after the time of diagnosis
(Greenlee et al, 2000). The current treatment includes a combination of surgery, chemotherapy, and radiation without any major improvement in survival (Azria et al, 2002). Over 10 years ago, it was hypothesised that $\mathrm{TNF} \alpha$ could increase tumour response to radiation through stimulation of the host antitumour immune responses, direct tumour-cell kill, or through the increase in tumour-cell sensitivity to radiation (Sersa et al, 1988; Hallahan et al, 1990; Gridley et al, 1994a, b; Kimura et al, 1999; Azria et al, 2003a). However, early clinical trials were generally disappointing, with hypotension and vascular leakage frequently being the doselimiting side effects (Chapman et al, 1987; Sherman et al, 1988). To overcome these limitations, we used a BAb directed against CEA and human $\mathrm{TNF} \alpha$ to target this cytokine to the human pancreatic carcinoma cells BxPC-3 treated simultaneously with RT.

In the first part of our study, we demonstrated direct cytotoxicity of $\mathrm{TNF} \alpha$ on BxPC-3 cells in culture using a clonogenic assay: TNF $\alpha$-treated BxPC-3 cells showed reduced plating efficiency (Figure 1), confirming that TNF $\alpha$ can be tumoristatic or tumoricidal as described for a variety of neoplastic cell types (Hallahan et al, 1990; Manetta et al, 1990; Gridley et al, 1994a; Kimura et al, 1999; Azria et al, 2003a). In a time-course experiment 


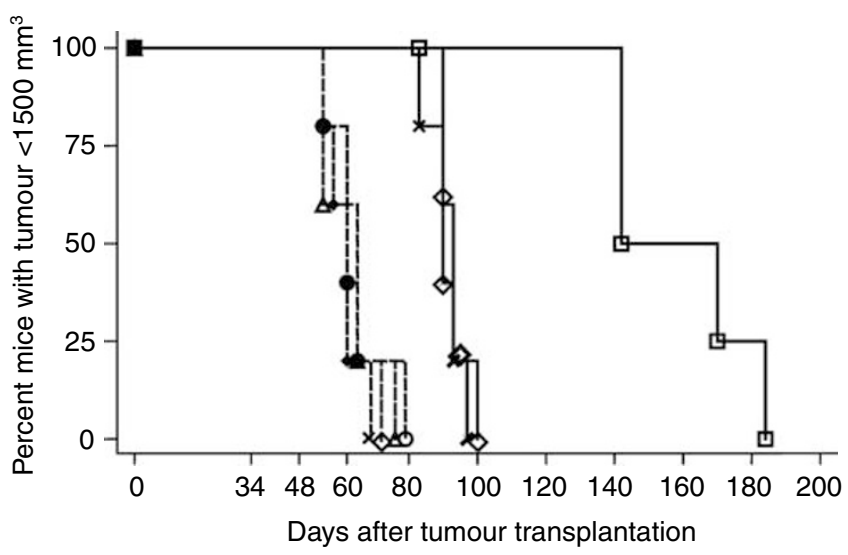

Figure 4 Kaplan-Meier survival curves obtained as a function of time for all groups: group I: dotted line $(O)$ no treatment (62 days); group 2: dotted line $(\diamond)$ TNF $\alpha$ (62 days); group 3: dotted line $(X)$ BAb (65 days); group 4: dotted line $(\triangle) B A b+T N F \alpha$ (62 days); group 5: solid line $(X) R T$ (90 days); group 6: solid line $(\diamond) \mathrm{RT}+\mathrm{TNF} \alpha$ (93 days); group 7: solid line ( $\square) R T+T N F \alpha+B A b(142$ days). The number in parentheses corresponds to the median delay (time taken for the tumour to reach a volume of $1500 \mathrm{~mm}^{3}$ in $50 \%$ of the mice).

(Figure 2), we demonstrated that maximal cell killing increase was obtained when TNF $\alpha$ was added to the cells $12 \mathrm{~h}$ before RT as compared with $1 \mathrm{~h}$ before and $12 \mathrm{~h}$ after RT. These data confirmed those published by Hallahan et al (1990), who demonstrated that addition of TNF $\alpha 4$ to $12 \mathrm{~h}$ prior to irradiation maximally increases cell killing.

We also observed that TNF $\alpha$ induced a $G_{1}$ cell cycle arrest and that cell exposure for $24 \mathrm{~h}$ to TNF $\alpha$ was sufficient to obtain this effect, which could be considered as irreversible since the $G_{1}$ arrest was maintained up to 21 days after elimination of TNF $\alpha$ from the culture medium (Table 1). This effect can probably be explained by modifications of the expression of cell-cycle-related proteins (ongoing research), as described for other cytokine such as interferon $\gamma$ (Matsuoka et al, 1999; Gooch et al, 2000), and by the fact that $\mathrm{TNF} \alpha$ induces BxPC-3 cycle distribution modification which may render the cells more radiosensitive. In the RT-TNF $\alpha$ combination treatment, we observed a $25 \%$ decrease of BxPC-3 cells arrested in the $G_{2}$ phase as compared with RT alone, a proportional redistribution in the $G_{1}$ phase, and an interrupted synthesis phase. We did not observe any induction of apoptosis in BxPC-3 cells, as previously suggested in another model (Gridley et al, 1994a) and recently described in a human prostate carcinoma cell line (Kimura et al, 1999). This cell cycle redistribution phenomenon may also explain the decrease in the surviving fraction in the combination treatment presented in the present study (Figure 1B). To our knowledge, these results are the first to confirm that TNF $\alpha$ is a biological cell cycle modifier, which is responsible for a cell cycle redistribution in the more radiosensitive $\left(G_{1}\right)$ phase rather than in the $S$ phase. Recently, Dormond et al (2002) described that TNF $\alpha$ alone or in combination with IFN $\gamma$ induced a $G_{1}$ arrest in endothelial cells (HUVEC), which was associated with reduced levels of cyclin D1 and cdk2, and with increased expression of the cdk inhibitors $\mathrm{p} 16^{\mathrm{INK} 4 \mathrm{a}}, \mathrm{p} 21^{\mathrm{WAF}}$, and $\mathrm{p} 27^{\mathrm{Kip} 1}$.

In the present study, the in vitro growth-inhibitory effect of TNF $\alpha$ was accompanied by a marked enhancement of the radioresponse of the tumour in vivo, particularly, when TNF $\alpha$ was concentrated in the tumour xenografts thanks to our BAb. In addition to the in vitro cytotoxic effect of $\mathrm{TNF} \alpha$, indirect in vivo mechanisms could be responsible for this synergistic rather than additive effect of the combination (Ruegg et al, 1998). Several studies have demonstrated the antitumour activity of RT $+\mathrm{TNF} \alpha$, but this treatment was given before the tumours reached a palpable volume, making a comparison with our results difficult (Gridley et al, 1994b, 1997). In mammary carcinoma and sarcoma models, $\mathrm{TNF} \alpha$ was shown to significantly increase tumour radiocurability even when TNF $\alpha$ was injected $3 \mathrm{~h}$ after RT (Sersa et al, 1988; Nishiguchi et al, 1990). Our data demonstrate the interest of targeting TNF $\alpha$ to tumours to improve RT and finally to keep a large differential effect between tumour and normal tissues. Various methods have recently tried to concentrate TNF $\alpha$ into tumour such as Cu2 +-dextran (Tabata et al, 1999), TNF $\alpha$-biotin conjugates (Moro et al, 1997; Gasparri et al, 1999), or liposomal encapsulated-TNF $\alpha$ (Kim et al, 2001) which are less specific targeting than our $\mathrm{BAb}$ and were not tested with concomitant radiotherapy.

Another approach currently in clinical evaluation uses an adenoviral vector that contains radio-inducible DNA sequences from the early growth response gene (EGR1) promoter and cDNA for the gene encoding human TNF $\alpha$. While avoiding the systemic side effects of TNF $\alpha$, this method involves injections in or near the tumour, which might be difficult to perform in the case of pelvic or retroperitoneal tumours (Weichselbaum et al, 2002).

Concerning the immunotargeting strategy, two attractive methods have been recently described. Cooke et al (2002) tested a genetic fusion of human recombinant TNF $\alpha$ with MFE-23, a single-chain $\mathrm{Fv}$ antibody fragment directed against CEA. Radiolabelled fusion protein binds both human and mouse TNF receptor 1 in vitro and in vivo and is able to localise effectively in nude mice-bearing human LS174T xenografts with a tumour/tissue ratios of $21: 1$ and $60: 1$ achieved 24 and $48 \mathrm{~h}$ after i.v. injection, respectively. The maximum \% injected dose (ID) $\mathrm{g}^{-1}$ LS174T tumour (4.33) was obtained $6 \mathrm{~h}$ postinjection. At that time, in T380 human colon carcinoma nude mice, our BAb was able to concentrate up to $7.15 \% \mathrm{ID} \mathrm{g}^{-1}$ of tumour as compared to $2.2 \%$ when BAb was injected alone (Robert et al, 1996). Wüest et al (2002) described a TNF $\alpha$ fusion protein designated TNF-Selectokine, which is a homotrimeric molecule comprised of a singlechain antibody ( $\mathrm{scFv}$ ) targeting molecule, a trimerisation domain and TNF $\alpha$. Membrane targeting dependent immobilisation of this TNF-Selectokine induced cell death in TNFR1 and TNFR2 dependent manner. The authors constructed, also, a TNFSelectokine prodrug by insertion of a TNFR1 fragment separated from TNF by a protease-sensitive linker in order to restrict TNF activity to the tumour. Both studies suggest interests but are in the early phase of development without any indications of their capacity of radiation enhancement.

The results of our study should be of potential clinical interest. They provide a rational for the combination of TNF $\alpha, \mathrm{BAb}$, and RT in the treatment of adenocarcinoma of the pancreas. One of the advantages of our BAb strategy, namely, the potential decrease of $\mathrm{TNF} \alpha$ systemic toxicity, cannot be addressed in our nude mice model, which lacks T cells. The difference between the TNF $\alpha+$ RT and the $\mathrm{BAb}+\mathrm{TNF} \alpha+\mathrm{RT}$ combination treatments will probably be even more evident in an immunocompetent model or in a clinical setting. Such an immunocompetent situation is also needed for the entire expression of TNF $\alpha$ antitumour action, including immunological (production of IL-1 and IFN $\gamma$, activation of macrophages, and NK cells; Dinarello et al, 1986; Ostensen et al, 1987; Talmadge et al, 1987) and nonimmunological mechanisms such as damage to the tumour vasculature (Gamble et al, 1985; Sato et al, 1986; Cavender et al, 1987; Ruegg et al, 1998).

In conclusion, we demonstrated that an anti-CEA/anti-TNF $\alpha$ $\mathrm{BAb}$ can markedly enhance the radioresponse of pancreatic tumour xenografts in nude mice. Presently, we are testing the antitumour effect of $\mathrm{BAb}, \mathrm{TNF} \alpha$, and $\mathrm{RT}$ combination in an immunocompetent CEA-transgenic mice transplanted with a syngenic CEA-expressing tumour in which all the effects of the targeted cytokine can be analysed. The next step will be the opening of a phase I clinical study in locally advanced pancreatic cancer. 


\section{ACKNOWLEDGEMENTS}

This study was supported by the comite de l'Hérault de la Ligue Nationale Contre le Cancer. David Azria was supported by the Association de Recherche sur le Cancer.

We thank Genevieve Heinz, Sabine Bousquié, Celine Passet, and Philippe Gauthier for excellent technical assistance;
Michel Brissac for help in performing animal experiments; Dr Jacques Dornand for the TNF $\alpha$ cytotoxicity assays; and Dr SL Salhi for critical comments and excellent editorial assistance. This work was presented in part at the Second International Conference of Translational Research and Preclinical Strategies in Radio-oncology, 16-19 March 2003 in Lugano, Switzerland.

\section{REFERENCES}

Abbruzzese JL, Levin B, Ajani JA, Faintuch JS, Saks S, Patt YZ, Edwards C, Ende K, Gutterman JU (1989) Phase I trial of recombinant human gamma-interferon and recombinant human tumor necrosis factor in patients with advanced gastrointestinal cancer. Cancer Res 49: 40574061

Andre T, Balosso J, Louvet C, Hannoun L, Houry S, Huguier M, Colonna M, Lotz JP, De Gramont A, Bellaiche A, Parc R, Touboul E, Izrael V (2000) Combined radiotherapy and chemotherapy (cisplatin and 5-fluorouracil) as palliative treatment for localized unresectable or adjuvant treatment for resected pancreatic adenocarcinoma: results of a feasibility study. Int J Radiat Oncol Biol Phys 46: $903-911$

Asher A, Mule JJ, Reichert CM, Shiloni E, Rosenberg SA (1987) Studies on the anti-tumor efficacy of systemically administered recombinant tumor necrosis factor against several murine tumors in vivo. J Immunol 138: $963-974$

Azria D, Dorvillius M, Gourgou S, Martineau P, Robert B, Pugnière M, Delard R, Ychou M, Dubois JB, Pèlegrin A (2003a) Enhancement of radiation therapy by tumor necrosis factor alpha in human colon cancer using a bispecific antibody. Int J Radiat Oncol Biol Phys 55: $1363-1373$

Azria D, Larbouret C, Martineau P, Robert B, Aillères N, Ychou M, Dubois JB, Pèlegrin A (2003b) A bispecific antibody against tumor necrosis factor alpha and carcinoembryonic antigen (CEA) to enhance radiation therapy in CEA-expressing digestive tumors. Int J Radiat Oncol Biol Phys, in press

Azria D, Ychou M, Jacot W, Thezenas S, Lemanski C, Senesse P, Prost P, Delard R, Masson B, Dubois JB (2002) Treatment of unresectable, locally advanced pancreatic adenocarcinoma with combined radiochemotherapy with 5-fluorouracil and cisplatin. Pancreas 25: $360-365$

Carswell EA, Old LJ, Kassel RL, Green S, Fiore N, Williamson B (1975) An endotoxin-induced serum factor that causes necrosis of tumors. Proc Natl Acad Sci USA 72: 3666 - 3670

Cavender D, Saegusa Y, Ziff M (1987) Stimulation of endothelial cell binding of lymphocytes by tumor necrosis factor. J Immunol 139: 1855 1860

Chapman PB, Lester TJ, Casper ES, Gabrilove JL, Wong GY, Kempin SJ, Gold PJ, Welt S, Warren RS, Starnes HF, Sherwin SA, Old LJ, Oettgen HF (1987) Clinical pharmacology of recombinant human tumor necrosis factor in patients with advanced cancer. J Clin Oncol 5: 1942-1951

Cooke SP, Pedley RB, Boden R, Begent RH, Chester KA (2002) In vivo tumor delivery of a recombinant single chain Fv::tumor necrosis factoralpha fusion [correction of factor: a fusion] protein. Bioconjug Chem 13: $7-15$

Dinarello CA, Cannon JG, Wolff SM, Bernheim HA, Beutler B, Cerami A, Figari IS, Palladino Jr MA, O'Connor JV (1986) Tumor necrosis factor (cachectin) is an endogenous pyrogen and induces production of interleukin 1. J Exp Med 163: $1433-1450$

Dormond O, Lejeune FJ, Rüegg C (2002) Modulation of cdk2, cyclin D1, p16INK4a, p21 WAF and p27 Kip1 expression in endothelial cells by TNF/IFN $\gamma$. Anticancer Res 22: 3159-3163

Gamble JR, Harlan JM, Klebanoff SJ, Vadas MA (1985) Stimulation of the adherence of neutrophils to umbilical vein endothelium by human recombinant tumor necrosis factor. Proc Natl Acad Sci USA 82: 8667 8671

Gasparri A, Moro M, Curnis F, Sacchi A, Pagano S, Veglia F, Casorati G, Siccardi AG, Dellabona P, Corti A (1999) Tumor pretargeting with avidin improves the therapeutic index of biotinylated tumor necrosis factor alpha in mouse models. Cancer Res 59: 2917-2923

Gooch JL, Herrera RE, Yee D (2000) The role of p21 in interferon gammamediated growth inhibition of human breast cancer cells. Cell Growth Differ 11: $335-342$

Greenlee RT, Murray T, Bolden S, Wingo PA (2000) Cancer statistics, 2000. CA Cancer J Clin 50: 7-33
Gridley DS, Archambeau JO, Andres MA, Mao XW, Wright K, Slater JM (1997) Tumor necrosis factor-alpha enhances antitumor effects of radiation against glioma xenografts. Oncol Res 9: $217-227$

Gridley DS, Glisson WC, Uhm JR (1994a) Interaction of tumour necrosis factor-alpha and radiation against human colon tumour cells. Ther Immunol 1: $25-31$

Gridley DS, Hammond SN, Liwnicz BH (1994b) Tumor necrosis factoralpha augments radiation effects against human colon tumor xenografts. Anticancer Res 14: 1107 - 1112

Gudjonsson B (1987) Cancer of the pancreas. 50 years of surgery. Cancer 60: $2284-2303$

Hallahan DE, Beckett MA, Kufe D, Weichselbaum RR (1990) The interaction between recombinant human tumor necrosis factor and radiation in 13 human tumor cell lines. Int J Radiat Oncol Biol Phys 19: $69-74$

Haskell CM, Buchegger F, Schreyer M, Carrel S, Mach JP (1983) Monoclonal antibodies to carcinoembryonic antigen: ionic strength as a factor in the selection of antibodies for immunoscintigraphy. Cancer Res 43: 3857 3864

Havell EA, Fiers W, North RJ (1988) The antitumor function of tumor necrosis factor (TNF). I. Therapeutic action of TNF against an established murine sarcoma is indirect, immunologically dependent, and limited by severe toxicity. J Exp Med 167: $1067-1085$

Helson L, Helson C, Green S (1979) Effects of murine tumor necrosis factor on heterotransplanted human tumors. Exp Cell Biol 47: $53-60$

Kim DW, Andres ML, Li J, Kajioka EH, Miller GM, Seynhaeve AL, Ten Hagen TL, Gridley DS (2001) Liposome-encapsulated tumor necrosis factor-alpha enhances the effects of radiation against human colon tumor xenografts. I Interferon Cytokine Res 21: 885-897

Kimura K, Bowen C, Spiegel S, Gelmann EP (1999) Tumor necrosis factoralpha sensitizes prostate cancer cells to gamma-irradiation-induced apoptosis. Cancer Res 59: $1606-1614$

Kornek GV, Schratter-Sehn A, Marczell A, Depisch D, Karner J, Krauss G, Haider K, Kwasny W, Locker G, Scheithauer W (2000) Treatment of unresectable, locally advanced pancreatic adenocarcinoma with combined radiochemotherapy with 5-fluorouracil, leucovorin and cisplatin. Br J Cancer 82: $98-103$

Langley RE, Palayoor ST, Coleman CN, Bump EA (1993) Modifiers of radiation-induced apoptosis. Radiat Res 136: $320-326$

Lejeune FJ, Ruegg C, Lienard D (1998) Clinical applications of TNF-alpha in cancer. Curr Opin Immunol 10: $573-580$

Lienard D, Ewalenko P, Delmotte JJ, Renard N, Lejeune FJ (1992) High-dose recombinant tumor necrosis factor alpha in combination with interferon gamma and melphalan in isolation perfusion of the limbs for melanoma and sarcoma. J Clin Oncol 10: 52-60

Manetta A, Lucci J, Soopikian J, Granger G, Berman ML, DiSaia PJ (1990) In vitro cytotoxicity of human recombinant tumor necrosis factor alpha in association with radiotherapy in a human ovarian carcinoma cell line. Gynecol Oncol 38: 200-202

Matsuoka M, Nishimoto I, Asano S (1999) Interferon-gamma impairs physiologic downregulation of cyclin-dependent kinase inhibitor, p27Kip1, during G1 phase progression in macrophages. Exp Hematol 27: $203-209$

Mavligit GM, Zukiwski AA, Charnsangavej C, Carrasco $\mathrm{CH}$, Wallace S, Gutterman JU (1992) Regional biologic therapy. Hepatic arterial infusion of recombinant human tumor necrosis factor in patients with liver metastases. Cancer 69: 557-561

Moritz T, Niederle N, Baumann J, May D, Kurschel E, Osieka R, Kempeni J, Schlick E, Schmidt CG (1989) Phase I study of recombinant human tumor necrosis factor alpha in advanced malignant disease. Cancer Immunol Immunother 29: $144-150$ 
Moro M, Pelagi M, Fulci G, Paganelli G, Dellabona P, Casorati G, Siccardi AG, Corti A (1997) Tumor cell targeting with antibody-avidin complexes and biotinylated tumor necrosis factor alpha. Cancer Res 57: $1922-1928$

Nishiguchi I, Willingham V, Milas L (1990) Tumor necrosis factor as an adjunct to fractionated radiotherapy in the treatment of murine tumors. Int J Radiat Oncol Biol Phys 18: 555-558

Ostensen ME, Thiele DL, Lipsky PE (1987) Tumor necrosis factor-alpha enhances cytolytic activity of human natural killer cells. J Immunol 138: $4185-4191$

Parker SL, Tong T, Bolden S, Wingo PA (1996) Cancer statistics, 1996. CA Cancer J Clin 46: 5-27

Robert B, Mach JP, Mani JC, Ychou M, Folli S, Artus JC, Pelegrin A (1996) Cytokine targeting in tumors using a bispecific antibody directed against carcinoembryonic antigen and tumor necrosis factor alpha. Cancer Res 56: $4758-4765$

Ruegg C, Yilmaz A, Bieler G, Bamat J, Chaubert P, Lejeune FJ (1998) Evidence for the involvement of endothelial cell integrin alphaVbeta3 in the disruption of the tumor vasculature induced by TNF and IFNgamma. Nat Med 4: 408-414

Sato N, Goto T, Haranaka K, Satomi N, Nariuchi H, Mano-Hirano Y, Sawasaki Y (1986) Actions of tumor necrosis factor on cultured vascular endothelial cells: morphologic modulation, growth inhibition, and cytotoxicity. J Natl Cancer Inst 76: 1113-1121

Sersa G, Willingham V, Milas L (1988) Anti-tumor effects of tumor necrosis factor alone or combined with radiotherapy. Int J Cancer 42 $129-134$

Sherman ML, Spriggs DR, Arthur KA, Imamura K, Frei III E, Kufe DW (1988) Recombinant human tumor necrosis factor administered as a five-day continuous infusion in cancer patients: phase I toxicity and effects on lipid metabolism. J Clin Oncol 6: 344-350
Sugarman BJ, Aggarwal BB, Hass PE, Figari IS, Palladino Jr MA, Shepard HM (1985) Recombinant human tumor necrosis factor-alpha: effects on proliferation of normal and transformed cells in vitro. Science 230: 943 - 945

Tabata Y, Noda Y, Matsui Y, Ikada Y (1999) Targeting of tumor necrosis factor to tumor by use of dextran and metal coordination. J Control Release 59: $187-196$

Talmadge JE, Tribble HR, Pennington RW, Phillips H, Wiltrout RH (1987) Immunomodulatory and immunotherapeutic properties of recombinant gamma-interferon and recombinant tumor necrosis factor in mice. Cancer Res 47: 2563-2570

Tan MH, Nowak NJ, Loor R, Ochi H, Sandberg AA, Lopez C, Pickren JW, Berjian R, Douglass Jr HO, Chu TM (1986) Characterization of a new primary human pancreatic tumor line. Cancer Invest 4: 15-23

van der Schelling GP, Ijzermans JNM, Kok TC, Scheringa M, Marquet RL, Splinter TA, Jeekel J (1992) A phase I study of local treatment of liver metastases with recombinant tumour necrosis factor. Eur J Cancer 28: $1073-1078$

Weichselbaum RR, Kufe DW, Hellman S, Rasmussen HS, King CR, Fischer $\mathrm{PH}$, Mauceri HJ (2002) Radiation-induced tumour necrosis factor-alpha expression: clinical application of transcriptional and physical targeting of gene therapy. Lancet Oncol 3: 665-671

Wüest T, Gerlach E, Banerjee D, Gerspach J, Moosmayer D, Pfizenmaier K (2002) TNF-Selectokine: a novel prodrug generated for tumor targeting and site-specific activation of tumor necrosis factor. Oncogene 21: 4257- 4265

Yamada T, Ohyama H (1988) Radiation-induced interphase death of rat thymocytes is internally programmed (apoptosis). Int J Radiat Biol Relat Stud Phys Chem Med 53: 65-75

Zimmerman RJ, Chan A, Leadon SA (1989) Oxidative damage in murine tumor cells treated in vitro by recombinant human tumor necrosis factor. Cancer Res 49: 1644-1648 